\title{
CORRELATION OF VEGATATIVE TONE INDICATOR WITH KERDO INDEX AND HEART RATE VARIABILITY
}

Introduction. Vegetative tone is traditionally evaluated with Kerdo index (KI). Recently, the method of determining the tone correlation of various parts of the autonomic nervous system with the indicators of heart rate variability (HRV) has been widely used. However, there are no comparative studies of these approaches.

Purpose. The purpose of the study was to investigate the links of Kerdo index with HRV indicators among athletes and non-sportsmen.

Methods. The measurements were carried out on 27 powerlifters (group I), 28 athletes of endurance events (group II) and 60 non-sportsmen (group III) at the age of 18-24 in conditions close to the basic circulation. The blood pressure and the registration of chest rheogram signals were measured in prone position at rest and tilt test for 5 minutes. The KI was evaluated based on HRV. The correlation analysis was conducted determining non-parametric Spearman coefficient.

Results. In prone position at rest in all groups, vagotonia was found and was expressed most in sportsmen training endurance. The athletes with strength training focus had higher level of the links of Kerdo index and HRV indicators. At tilt test, the correlation of HRV and KI increased in group II sportsmen at rest, remained high in group I sportsmen and increased slightly in non-sportsmen.

Conclusion. In the groups of sportsmen, the most stableand high links were found between Kerdo index and rMSSD and pNN50, which might be recommended for evaluating vegetative tone in training process.

Keywords: heart rate variability, vegetative tone.

Problem statement. The analysis of heart rate variability (HRV) is widespread among the modern information technologies of determining the functional state of healthy people organism. However, the physiological interpretation of some indicators of computer analysis of fluctuation frequency of heart rate is not fully substantiated. It also concerns the evaluation of vegetative tone by HRV. Traditionally, vegetative tone is evaluated by Kerdo index (KI) [1].

Analysis of recent research and publications. HRV under the influence of physical activity was investigated by many authors $[2,3,4,5]$. The HRV indicators proved to be reliable and predictive for evaluating sportsmen's functional state. However, the accuracy problem of characterizing vegetative tone level by means of HRV is controversial by this time.

Research goal and tasks. The goal of the research was to study the links of Kerdo index with HRV indicators in athletes and non-sportsmen. To achieve the goal we had to solve the following tasks: to analyze the KI level in athletes with different training focus and in non-sportsmen; to conduct correlation analysis of KI and the HRV indicators in prone position at rest; to conduct correlation analysis of KI at rest and the HRV indicators at tilt test.

\section{Methods}

27 powerlifters (group I), 28 athletes of endurance events (group II) and 60 nonsportsmen aged 18-24 were studied in the conditions close to basic circulation adhering the requirements of bioethical provisions of the Council of Europe Convention on Human Rights and Biomedicine (1997), the Declaration of the Helsinki World Medical Association on the ethical principles of conducting human medical research (1994-2008).

Blood pressure and the registration of chest rheogram signals were measured for 5 minutes in prone position at rest and tilt test. Kerdo index was determined with the formula of $\mathrm{KI}=100 *(1-\mathrm{APd} / \mathrm{HR})$ (where APd - diastolic arterial pressure, HR - heart rate). The following indicators of HRV were determined: amplitude mode (aMo); cardio interval scatter (DX); voltage index for Baevsky (IN); standard deviation of cardio intervals (SDNN); RMSSD - the square root of the average sum of squares of differences between adjacent 
cardio intervals; pNN50 - the number of adjacent cardio intervals with a difference of more than $50 \mathrm{~ms}$ divided by the total number of cardio intervals; oscillation power of cardio intervals in the ranges of $0-0.04 \mathrm{~Hz}$ (VLF), $0.04-0.15 \mathrm{~Hz}$ (LF), $0.15-0.4 \mathrm{~Hz}$ (HF), 0-0.4 Hz (TP); normalized power in the range of 0.15-0.4 Hz (HFnorm) in the Caspico program [6].

In the statistical analysis of the KI, the mean value and its error were determined with the estimation of the differences according to Student's t-criterion. Correlation analysis was carried out with the definition of Spearman's nonparametric coefficient.

\section{Results and their Discussion}

In prone position at rest, KI in different groups had the following levels: $-28.7 \pm 3.8$ c.u. (group I), $-45.7 \pm 5.8$ c.u. (group II), $-14.3 \pm 2.2$ c.u. (group III). There are reliable $(\mathrm{p}<0.001$ ) differences among all these values. Thus, vagotonia was found in all groups and expressed in the highest degree in sportsmen training endurance. Such a pattern is consistent with the generally accepted notions of economizing the human body work at rest under the influence of regular aerobic activities.

The following data were found in the correlation analysis of KI correlation with HRV indicators in the prone position at rest (Table).

Table 1

Correlation coefficients between Kerdo index and heart rate variability in athletes with different training focus and non-sportsmen

\begin{tabular}{|l|c|c|c|c|c|c|}
\hline \multirow{2}{*}{ Indicators } & \multicolumn{3}{|c|}{ Prone position at rest } & \multicolumn{3}{c|}{ Tilt test } \\
\cline { 2 - 7 } & I & II & III & I & II & III \\
\hline HR & 0.81 & 0.97 & 0.75 & 0.51 & 0.82 & 0.51 \\
\hline aMo & 0.73 & 0.29 & 0.34 & 0.72 & 0.36 & 0.34 \\
\hline DX & -0.47 & -0.06 & -0.11 & -0.63 & -0.50 & -0.28 \\
\hline IN & 0.74 & 0.40 & 0.38 & 0.72 & 0.47 & 0.42 \\
\hline SDNN & -0.80 & -0.25 & -0.25 & -0.67 & -0.36 & -0.40 \\
\hline rMSSD & -0.82 & -0.35 & -0.33 & -0.68 & -0.67 & -0.31 \\
\hline pNN & -0.83 & -0.47 & -0.41 & -0.65 & -0.68 & -0.31 \\
\hline VLF & -0.71 & -0.34 & -0.05 & -0.67 & -0.30 & -0.44 \\
\hline LF & -0.66 & -0.04 & -0.31 & -0.52 & -0.11 & -0.41 \\
\hline HF & -0.79 & -0.33 & -0.36 & -0.68 & -0.45 & -0.25 \\
\hline HF & -0.50 & -0.34 & -0.06 & -0.47 & -0.38 & 0.08 \\
\hline TP & -0.80 & -0.29 & -0.30 & -0.67 & -0.36 & -0.40 \\
\hline
\end{tabular}

The highest correlation was found between KIand HR. It is explained by the fact that KI is calculated on the basis of this indicator. The most dense links were found in athletes of group I (from -0.47 till 0.82), the level of athletes in group II and non-sportsmen was not high (the highest being -0.47). In group II of athletes, the factor decreasing the density of the links can be the availability of persons with relatively low frequency of respiration [7]. Relatively low correlation between $\mathrm{KI}$ and $\mathrm{HF}_{\text {norm }}$ draw our attention; the indicator of it is positioned as a feature of vegetative tone by some authors. At the same time, rMSSD and pNN50 had the highest correlation with $\mathrm{KI}$.

At tilt test, the correlation of HRV with KI increased at rest in the athletes of group II, remained high in the sportsmen of group I, increased slightly in non-sportsmen. The most stable and high links with KI in these conditions were found with rMSSD and pNN50. Previously, it has been shown that the reactivity of HRV, in contrast to the reactivity of blood pressure indicators, has significant individual characteristics with the change of the 
body position of healthy young men that may cause changes in the correlation of these indicators [8].

\section{Conclusions}

1. Vagotonia is found in the prone position at rest and expressed in the highest degree in the athletes training endurance.

2. The sportsmen with strength focus of their training process have the highest level of correlation of Kerdo index with HRV indicators.

3. In sportsmen groups, the most stable and high links are found between Kerdo index with rMSSD and pNN50, which can be recommended for evaluation of vegetative tone in the training process.

\section{References}

1. Kérdö I. (1966). Ein aus Daten der Blutzirkulation kalkulierter Index zur Beurteilung der vegetativen Tonuslage. Acta neurovegetativa. 2. 250-268.(in De).

2. Kovalenko S.O., Kudiy L.I. (2016). Heart Rate Variability. Methodical aspects. Cherkasy: Cherkas'kyy natsional'nyy universytet im. B. Khmel'nyts'koho. 298. (in Ukr.)

3. Cornell D. J., Paxson J. L.,Caplinger R. A., Seligman J. R., Davis N. A. (2017). Ebersole K.T.Resting Heart RateVariabilityAmong Professional Baseball Starting Pitchers. J Strength Cond Res.2017 Mar;31(3):575581. doi: 10.1519/JSC.0000000000001538.

4. Kiss O., Sydó N., Vargha P., Vágó H., Czimbalmos C., Édes E., Zima E., Apponyi G., Merkely G., Sydó T., Becker D., Allison T.G., Merkely B. (2016). Detailed heart ratevariability analysis in athletes. Clin Auton Res. Aug;26(4):245-52. doi:10.1007/s10286-016-0360-z

5. Molina G.E.,Fontana K.E.,Porto L.G.,Junqueira L.F. (2016). Post-exerciseheart-raterecovery correlates to restingheart-ratevariabilityin healthy men. Clin Auton Res.2016;26(6):415-421. doi:10.1007/s10286-016$0378-2$.

6. Kovalenko S.O., Yakovlev M.Ye. (2005). The computer program for registration and analysis of heart rate and respiration ("CASPICO"). The author testimony of Ukraine №11262, Abstract in the official journal "Copyright and Related Rights", 6. 338. (in Ukr)

7. KovalenkoS.O., KudiyL.I., Kalenychenko O.V. (2004). Heart rhythm variability in individuals with different respiration frequency. Fiziol Zn. 50, 6. 43-7.

8. Kovalenko S.O., Kudij L.I. (2002). Analysis of deviation reactions of heart rhythm at the changes of position of body. Visnyk Cherkas'koho universytetu. Seriya biolohichni nauky (Bulletin of Cherkasy University. Biological sciences series). 39. 70-74. (in Ukr)

\section{References (in language original)}

1. Kérdö I. Ein aus Daten der Blutzirkulation kalkulierter Index zur Beurteilung der vegetativen Tonuslage / I. Kérdö // Acta neurovegetativa. — 1966. — № 2. - P. 250-268. (in De).

2. Коваленко С.О.Варіабельність серцевого ритму.Методичні аспекти / С. Коваленко, Л. Кудій. - Ч: Черкаський національний університет ім. Б. Хмельницького, 2016. - 298 с.

3. CornellD.J. EbersoleK.T. RestingHeartRateVariabilityAmongProfessionalBaseballStartingPitchers / D.J. Cornell, J.L.Paxson, R.A.Caplinger, J.R.Seligman, N.A. Davis // J Strength Cond Res. - 2017. № 31(3). P. 575-581. doi: 10.1519/JSC.0000000000001538.

4. Kiss O. Detailed heart rate variability analysis in athletes / O. Kiss, N. Sydó, P. Vargha, H. Vágó, C. Czimbalmos, E. Édes, E. Zima, G. Apponyi, G. Merkely, T. Sydó, D. Becker, T.G. Allison, B. Merkely // Clin Auton Res. - 2016. - № 26(4). - P. 245-52. doi:10.1007/s10286-016-0360-z

5. Molina G.E. Post-exerciseheart-raterecovery correlates to restingheart-ratevariabilityin healthy men / G. E. Molina, K.E. Fontana, L.G. Porto, L.F. Junqueira // Clin Auton Res. - 2016. - № 26(6). - P. 415-421. doi:10.1007/s10286-016-0378-2.

6. Коваленко С. О. Комп’ютерна програма для реєстрації та аналізу ритму серця і дихання ("CASPICO"). Авторське свідоцтво України №11262 / С.О. Коваленко, М.Е.Яковлєв // Авторське право та суміжні права. - 2005. - №6. - С. 338.

7. Kovalenko S. O. Heart rhythm variability in individuals with different respiration frequency / S. O. Kovalenko, L .I. Kudiy, O. V. Kalenychenko // Fiziol Zn. - 2004. - №50. - P. 43-47.

8. Коваленко С. О. Аналіз варіативності реакцій серцевого ритму при змінах положення тіла / С. О. Коваленко, Л. І. Кудій // Вісник Черкаського університету. Серія біологічні науки (Bulletin of Cherkasy University. Biological sciences series). - 2002. - №39. - C. 70-74. 
Sиттагу. О. І. Андрощук, В. А. Завгородня. Зв'язки показника вегетативного тонусу за індексом Кердо та варіабельністю серцевого ритму.

Introduction. Традииійно вегетативний тонус оцінюють за індексом Кердо (IК). Останнім часом широко розповсюджений метод визначення співвідношення тонусу різних ланок вегетативної нервової системи за показниками варіабельності сериевого (ВСР) ритму. Втім досліджень з порівняннями изих підходів немає.

Purpose. Метою дослідження було вивчити зв 'язки індекса Кердо з показниками ВСР у спортсменів та осіб, щзо не займаються спортом.

Methods. Вимірювання проведені на 27 спортсменах пауерліфтерах (I група), $28-$ y видах на витривалість (II група) і 60 неспортсменах (III група) віком від 18 до 24 років в умовах, наближених до основного обміну. Здійснювали вимірювання артеріального тиску та реєстрачію сигналів реограми грудної клітки упродовж 5 хвилин у спокої лежачи та при проведенні ортопроби. Очінювали IK та основні показники ВСР. Кореляційний аналіз проводили з визначенням непараметричного коефіиієнту Spearman

Results. B стані спокою лежачи у всіх групах спостерігалась ваготонія у найбільшому ступені виражена у спортсменів, щзо тренують витривалість. Спортмени з силовою спрямованістю тренувального проиесу мають більш високий рівень зв'язків індексу Кердо з показниками ВСР. При ортопробі у спортсменів II групи кореляиї ВСР з IК в спокої збільшуються, у спортсменів I групи залишаються високими, а у не спортсменів - зростають незначно.

Conclusion. У групах спортсменів найбіш стабільні та високі зв'язки відмічені між індексом Кердо та rMSSD i pNN50, котрі можна рекомендувати для оцінки вегетативного тонусу у тренувальному процесі.

Keywords: варіабельність серцевого ритму, вегетативний тонус

\section{Черкаський національний університет ім. Б. Хмельницького}

$\begin{array}{lr}\text { Одержано редакцією } & 06.03 .2017 \\ \text { Прийнято до публікації } & 11.06 .2018\end{array}$

